\title{
Creative methodologies for understanding a creative industry
}

\author{
Ted Fuller \\ Lincoln Business School, University of LincolnBrayford Pool, Lincoln, LN6 7TS, United Kingdom \\ Tel: +441522886142 \\ Email: tfuller@lincoln.ac.uk
}

\section{Lorraine Warren}

School of Management, University of Southampton, Highfield, Southampton, SO17 1BJ, United Kingdom Email: I.warren@soton.ac.uk

Sally Jane Norman

Culture Lab, University of Newcastle, Newcastle upon Tyne NE1 7RU, United Kingdom s.j.norman@ncl.ac.uk

\section{Key words}

Entrepreneurship; complexity; emergence; creative industry; methodology; value creating systems

\section{Summary}

The paper presents a conceptual framework for the identification and analysis of value creating and value capture systems within creative industry contexts based on theoretical and empirical studies.

\begin{abstract}
Objectives

The production of innovation or novelty in creative interactions is normally represented in research either as normative patterns of behaviour (being creative) or as post-hoc empirical objects (new firms, new products etc.) The structure of creative practices, i.e. what particular forms of interactivity produce successful novelty (i.e. which becomes 'normal' and not novel, which creates and captures value), is not well researched. This paper provides a 'digital economy' perspective of the creative industries as a micro-level example of a wider analytical problem, which is how society changes itself. The increasing level of innovation and creativity produces greater levels of instability in social structures (habits, norms etc.) Completely new industries can arise (and 'creatively' destroy old ones) as new stabilised patterns form, particularly where entry costs are tumbling, such as digital milieu.
\end{abstract}

\section{Prior Work}

The authors have undertaken a stream of research that utilises the field of entrepreneurship to study the emergence of novelty. This has been informed by entrepreneurship theories (e.g. effectuation), by complexity theory (e.g. emergence) by constructionist theory (e.g. patterning and identity formation) and by critical realism (morphological perspectives).

\section{Approach}

Observations of workshops over several days with creative groups, interviews with creative enterprises, literature reviews on creative industries, business models and value systems have informed the analysis and conceptualisation.

\section{Results}

We present a conceptual framework that we suggest can capture how novelty arises as emergent order over time. We have extended previous work that investigates the significance of emergence in theorising entrepreneurship into an exploration of how to articulate the creation and flow of value and effective ontology in a creative landscape

\section{Implications}

In the digital economy, the creative industries revolve around dynamic, innovative and often unorthodox collaborations, whereby numerous large, small and micro-businesses come together for the duration of a project, then disband and form new partnerships for the next project. Research designs must therefore address multiple contexts and levels presenting an analytical challenge to researchers.

Value

Methodologically, we suggest that the framework has analytical potential to support the collection of data: ordering and categorising empirical observations concerning how different phenomena emerge over time across multiple levels of analysis and contexts. Conceptually, the work broadens the notions of 'business model' to consider value creating systems and particular states reached by those systems in their evolution. 


\section{Creative methodologies for understanding a creative industry}

\section{Introduction}

We have previously undertaken a stream of research that utilises the field of entrepreneurship to study the emergence of novelty, that is, the processes by which new products, services, business models and patterns of behaviour arise through creative acts. (Fuller et al, 2007; Fuller et al, 2004; Fuller and Warren, 2006a, b; Fuller and Moran (2000, 2001); Lichtenstein 2000a,b,c; McKelvey 2004).As we summarise briefly below, this has been informed by entrepreneurship theories (e.g. effectuation), by constructionist theory (e.g., patterning and identity formation), by critical realism (morphological perspectives) and by theories of social change (e.g. structuration). In particular, we have demonstrated the value of complexity theory (notably 'processes of emergence') in conceptualising the practice of agility and foresight in the entrepreneurial firms we have studied.

In this paper, we seek to extend previous conceptual work by articulating the development of a conceptually grounded framework that we suggest can capture the emergence of novelty in the creative industries, particularly those in the so-called Digital Economy. As we indicate below, the Digital Economy, through the internet, improved communications and a range of web 2.0 platforms provide enormous potential for the creation of novelty as defined above, in ways that are hard to predict given the unexplored potential of many new technologies and the ongoing pace of technological change. Unexpected new ways of creating value have arisen on a system-wide basis, albeit that revenue streams for many new activities are not well understood or established. Better understanding of how new value creating systems emerge in such landscapes can give us a better understanding of how such processes can be managed and supported, thereby contributing, in a small way, to better understanding of the sustainability of the industries overall.

This is important economically, as the UK is renowned for its creative industries in areas as diverse as music, animation, design, gaming and the visual and creative arts. It has been estimated that the creative industries account for $7.3 \%$ of the UK economy, parallel in size therefore to the financial services industry (DCMS, 2007). The livelihood of a growing proportion of UK citizens therefore depends upon the sector maintaining its growth trajectory, particularly in the South East. Together with London and parts of the East of England and South West, the South East region forms a "mega region" of world-class significance in relation to the creative economy. The David Powell report (2002) suggests that the creative industries employ more than half a million people in the South East and contribute more than 40 billion to the regional economy. Creative and cultural industries represent around 30 per cent of its GDP, making it our region's fastest growing sector. Good understanding of the challenges and opportunities presented by the sector is therefore important from a regional development point of view.

Yet studying the sector presents challenges:

- Firstly, the 'creative industries' are very diverse, spanning a range of interlocking industries, including arts, culture, heritage, media, gaming, performance and occasionally sports; the production of both (aesthetic) artefacts and also surrounding services must also be considered.

- Secondly, developments in digital technology have stimulated new impetus for rapid change over the last decade, presenting unlimited possibilities for new resonances between social practices and values and the techno-creative milieu. For example, disintermediation in the music industry has been made possible through the internet, which allows new experiences anywhere/anytime, resulting in new behaviours in respect of the production and consumption of artistic output. Of course, this has had a profound effect on the power base in the industry, as old business models have been swept aside - at times, before new revenue streams have been established.

- Thirdly, the creative industries have a distinctive character that challenges traditional models of research into business innovation and entrepreneurship. Specifically, the creative industries revolve around entrepreneurial, innovative and often unorthodox collaborations, whereby numerous large, small and micro-businesses come together for the duration of a single project, then disband and form new partnerships for the next project. This diversity, fluidity, interconnectedness and potential range of novel new combinations for which there may be currently no precedent presents a challenge for researchers, educators and policymakers who want to not only know, but explain, and further, anticipate, what is going on, so that appropriate development and support mechanisms might be put in place. Inevitably then, our research designs must address multiple contexts and levels presenting an analytical challenge to management researchers (Pettigrew et al, 2001).

The vehicle that is allowing us to further test our central argument is www.creatorproject.org. The Creator project is a research cluster funded by EPSRC (EP/G002088/1) as part of the "Connecting Communities for the Digital Economy. 
Our approach was to work with actors in live projects in order to examine how novelty emerges over time in dynamic fluid domains where uncertainty is high and outcomes are indeterminate. Firstly, we carried out an internet-based case study of Blast Theory/Rider Spoke :

< http://www.blasttheory.co.uk/bt/work rider spoke.html>, to generate understanding of concepts such as pervasive computing, ubiquitous computing, urban sensing, and the ecosystems surrounding them. Secondly, we carried out interviews and discussions with staff at IT-Innovation, a company involved in developing a new business model for a portal in the post-production rendering industries in Soho < http://www.itinnovation.soton.ac.uk/>. Thirdly, we carried out participant observations of interactions in Proboscis' Sensory Threads project < http://proboscis.org.uk/projects/sensory-threads/> and the Gesture and Embodied Interaction workshops at Newcastle and Cambridge:

$<$ http://www.ncl.ac.uk/culturelab/assets/pdfs/Gesture and Embodied Interaction Article Jan09.pdf $>$. We explored how novelty emerged through interactions between the actors in the projects, and how novelty was related to value creation and the possible engagement of [new] external stakeholders.

\section{Theoretical Development}

Thus far in our work, our overarching research question has been, How do processes of entrepreneurship result in the emergence of new phenomena (new products, services, value creating systems) in particular social or industry contexts? While the agential dimension of entrepreneurship suggests that acts of creativity are significant in initiating change, the emphasis on context too is very significant. We argue that to remain fit over time in the dynamic, fluid landscape of the creative industries, it will be essential that creative firms constantly organise for novelty in anticipation of new collaborations, new networks and new patterns of consumer behaviour. This need is heightened by desirable heterogeneity of actors engaged in the creative landscape, since innovation tends to spring from the fertile boundaries of previously dissociated areas of activity. Sustaining creative diversity through broad-based satisficing (Simon 1957) rather than quick-win optimisation approaches is likely to more effectively enhance the dynamics of such communities. Those seeking to engage will have to act on contingency, where strategy is what is possible in an environment where the future is unpredictable e.g. (Sarasvathy 2001), fast moving and contains many actors, artefacts and potential collaborators that may co-evolve in complex non-linear ways. Yet, as Lichtenstein et al (2006) discuss, the study of system-wide dynamics is challenging, as the process can span long periods of time and many modes of activity take place across different contexts (Low and MacMillan 1988). An obvious approach to dealing with this fluidity is to simplify research designs by focussing on one level of analysis, in most cases the individual, the firm or the industry. Yet this can only lead to partial, impoverished pictures of what is surely a far more rich and vibrant milieu. Hence, we have turned to complexity theory for a more integrated approach.

Management theorists' interest in complexity theory is based firstly, on complexity's emphasis on order creation in open, non-linear, dynamic systems, a view that resonates with similar themes in organisational theory, and secondly, the potential to theorise (through the notion of emergence) across multiple levels of analysis, such as individuals, firms and the broader environment. Using a metaphorical language for change and development (Lissack 1997), complexity theory has been used in the design of organisational strategies (Burnes 2005; Houchin and MacLean 2005; Lichtenstein et al 2006; Lichtenstein 2000a; Stacey et al, 2002; Stacey, 2003). Concomitantly, the value of complexity theory in theorising entrepreneurship has been recognised (Fuller et al, 2007; Fuller et al, 2004; Fuller and Warren, 2006a, b; Fuller and Moran (2000, 2001); Lichtenstein 2000a,b,c; McKelvey 2004).). McKelvey (2004) contends that this approach is relevant because at a deep theoretical level it is consonant with the creative destruction of Schumpeterian entrepreneurship (Schumpeter 1934), where entrepreneurship is defined as discontinuous change that destroys economic equilibria. Old orders are destroyed, new economic 'orders', are created in contexts that are far from equilibrium. In this vein, 'emergence' is a powerful trope that can capture the way novel structures come into being; in general terms, conjunctions of forces can produce an outcome that is more than, or at least behaves differently from, the sum of its constituent parts.

While the mainstream literature on entrepreneurship includes notions of emergence, in particular the emergence of new enterprises and products, (for example, Busenitz et al, 2003; Fischer et al, 1997; Fleming and Sorenson, 2001; Gartner 1993; Garud and Karnoe, 2001), complexity theory suggests that there are some gaps that merit further study (Fuller et al, 2008). Lichtenstein et al (2007, p. 238-40) argue that there should be more focus on the dynamic processes and conditions that lead to the emergence of novelty, rather than what emerges and when. They argue that interdependent patterns of wide-ranging entrepreneurial activities, rather than individual acts such as creating business plans, are significant in initiating processes of emergence towards novelty. This implies that entrepreneurs must combine advanced thinking processes and time- and life-management skills, sustaining a multi-dimensional focus for many months at a time and by implication, a high degree of entrepreneurial competence, agility and foresight. In the creative industries, they must also maintain high artistic and cultural acumen. 
Further, although Fuller and Moran (2001) suggest that these patterns of behaviour operate through multiple hierarchical structural levels, there has also been a tendency to reify entrepreneurship as the activities of individuals (entrepreneurs) within the process. Even where a broader 'system-wide' view is taken, as in Lichtenstein et al (2007), the scope is limited, still largely centring on the individual. Yet, as Low and McMillan (1988) and Aldrich and Martinez (2001) point out, to understand entrepreneurship, one needs to understand the interaction between process and context, strategies and outcomes. There are a few studies that analyse organizational emergence and entrepreneurial behaviour related to the embeddedness of entrepreneurship, drawing on sociological theory such as Gidden's structuration theory (e.g., Jack and Anderson, 2002), the concept of structural embeddedness (e.g., Simsek, Lubatkin and Floyd, 2003) or institutional approaches (e.g., Smallbone and Welter, 2006) and social constructionist approaches (Fletcher, 2006; Down, 2006), and in doing so, they add different contextual viewpoints, albeit implicitly. However, this question of multiple levels of analysis and multilevel theory building is still a key issue for entrepreneurship research (Davidsson and Wiklund 2001; Phan, 2004) in particular because of the widening contexts in which both discourse and the practice of entrepreneurship are engaged, for example in corporate and public contexts as well as individually founded firms. Given the economic and political significance of the creative industries agenda, the need to develop entrepreneurial competence and improve outcomes is clear.

The above discussion suggests that it may be useful to research how patterns of behaviour that span process and context arise, leading to better understanding of how novelty emerges in entrepreneurial firms. While complexity theory suggests that it is not possible to predict or determine outcomes in advance, Snowden (2002), Stacey (2003) and Lichtenstein et al (2007) suggest that understanding how meaningful patterns of behaviour emerge over time in a system-wide manner can enhance the likelihood of desirable outcomes through increasing performance generally. These patterns impact systemically at the firm level and beyond, through a wider network of stakeholder relationships that are mediated by the social and cultural relations in and surrounding the firm. For the creative industries, there can be tensions around the notion of realising economic value from artistic, cultural or creative endeavour, particularly where the content is seen as subversive, or critical of the financial or political establishment.

Of course, the power to achieve a particular stated goal is limited for any small firm or collaboration, particularly in dynamic industries dominated by influential incumbents, (unless it controls the market entrance of a disruptive innovation: Christensen, 1997). Entrepreneurs have to act on contingency, where strategy is what is possible in an environment where the future is unpredictable e.g. (Sarasvathy 2001), and often dominated by large firms and fast-moving technological and industrial standards that co-evolve in complex non-linear ways (Garnsey and Heffernan 2005). Yet to remain fit over time, it is essential that the entrepreneurial small firm constantly organises for novelty in anticipation of industry change, particularly in high-velocity industries where uncertainty is high. Lichtenstein (2000b) shows how in each of four high technology business start-ups the business model had to be changed several times before becoming stable, relative to an unstable and unpredictable environment.

Furthermore if it is to be successfully sustained, not only does the creative output of entrepreneurship need to be 'novel', it also has to be perceived as valuable in use or in exchange; by being "novel and appropriate, useful, correct or a valuable response to the task at hand" (Amabile 1996: 35, quoted in Lepak et al 2007). This is of particular sensitivity in the field of creative industries, given the unpredictability of the perceived value of many artistic and creative endeavours, which we discuss later in the paper. Hearn et al (2007) suggest that it would be unwise to adopt uncritically models derived from other industry sectors without considering the particular dynamic of the creative industries. They argue for 'value creating ecologies', where value creation is not a readily understood one-way process, as implied by the value chain, but instead involves systemic processes of reiteration, feedback and co-creation on the part of consumers as well as producers, where the lines between production and consumption are increasingly blurred.

We found Chesbrough's distinction between value creation and value capture to be a helpful analytical difference when considering some of the cases in this research. (Chesbrough 2006, p 2): However, it is clear from the body of knowledge on value creation and value capture e.g. (Lepak et al 2007), that these concepts are contestable and open to multiple interpretations. Significantly, as Lepak et al assert, value creation and capture (and, we suggest, intermediate processes), operate at multiple levels. The relationship between value creation and its capture and the systems in which value is produced and enjoyed is a continuing field of study, to which this paper contributes.

Fuller et al (2004) and Fuller and Warren (2006a,b), and Fuller et al (2007) have reported 4 inter-related behaviour patterns, or 'processes of emergence' that lead to the emergence of novelty in entrepreneurial settings in different industries: new business models, new products, new careers. These processes of 
emergence, set out in Table 1, have been characterised as the 'EROS' model - Experiments, Reflexivity, Organising, Sensitivity.

Table 1: EROS Processes of Emergence

\begin{tabular}{|l|l|}
\hline Process & Behaviour \\
\hline Experimenting & $\begin{array}{l}\text { Diverse exploratory behaviours that might (or might not) become part of the firm over } \\
\text { time; new things tried out in often very informal ways, small scale; often developed } \\
\text { through exploration of social interactions; shared experiential learning across project } \\
\text { teams and stakeholders; 'what works' }\end{array}$ \\
\hline Reflexivity & $\begin{array}{l}\text { Continuous reflection on the identity of the firm and the self-identity of its owner(s) } \\
\text { through the discourses within the business and with stakeholders; vision setting } \\
\text { through narratives of self and firm; 'who we are' }\end{array}$ \\
\hline Organising & $\begin{array}{l}\text { Organising around a dominant logic (or project); patterns established through } \\
\text { negotiated practice; pattern-making and pattern-breaking; 'what needs to be done } \\
\text { now' }\end{array}$ \\
\hline Sensitivity & $\begin{array}{l}\text { Interpretation of shifts in industry landscape; detection of difference; weak signals; } \\
\text { triggers and thresholds for change; 'what we might do' }\end{array}$ \\
\hline
\end{tabular}

The processes in Table 1 should be seen as interconnected, not separate, and we argue that it is the multidimensional concentration on these patterns of behaviour that is at the heart of entrepreneurial competence through effective strategising over time to produce a sustainable endeavour. The four EROS processes interact to produce new emergent structures over time. Each process inter-relates with the other through multi-layers of cognition, language, performance and relationships with others, albeit strongly influenced by the entrepreneur. Further, on examining the 'stability' of a firm that had been in existence for about 20 years in a fast moving environment we concluded that its ontology at periods in that history was manifest in an ongoing set of temporary stable emergents and ephemeral structures, reflecting Sawyer's (2005) 'Emergence Paradigm' of social structures that (influenced by Archer's work, 1995) posits a hierarchical model of individual, interaction, ephemeral emergents, stable emergents, and social structures (see Figure 1).

We have identified such temporary structures in our early empirical work in this domain. They seem to include particular business models, particular identities, particular dominant logics, particular triggers for change etc. Within that milieu, some were more stable than others and became part of the business; others initially commanded intensive resource and attention, but were not developed through to fruition. Nonetheless, even ephemeral and unstable structures that did not persist, exhibited ontological status and considerable causal power - at least for a time, as the firm sought to make its way forward in a highly uncertain environment. There was a dynamic tension, the self-identity of the entrepreneur and the identity of the firm which was highly stable and causal to the dynamics and direction of the firm. Similarly, the 'stable' structural nature of economic systems provided a constraining framework (you have to make profits, pay staff etc.). However the instability of the industry, created mainly by new technology, deregulation and therefore greater competition provided a downward causation on the (in)stability of the emergents of the firm, for example, on their everyday practices, everyday discourse patterns, types of collaboration, potential new projects and the intentions of the entrepreneurs involved. 
Figure 1.The Emergence Paradigm.

\section{Social Structure (Level E)}

Written texts (procedures, laws, regulations); material systems and infrastructures (architecture,urbandesign,communication and transport

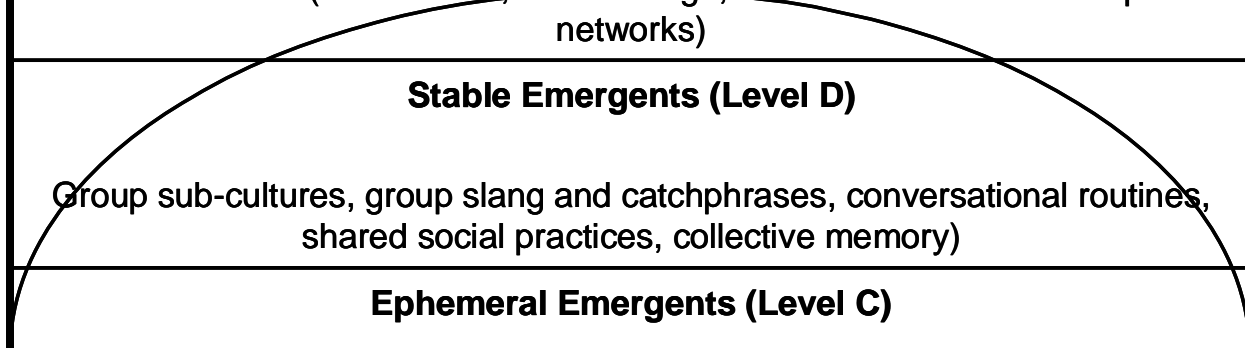

Topic, context, inter-actional frame, participation structure; relative role and

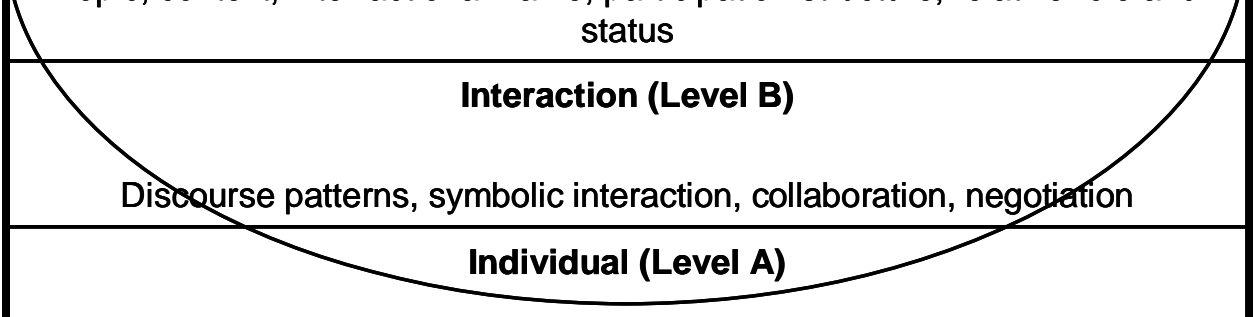

Intention, agency, personality, cognitive process

The Emergence Paradigm (Sawyer 2005, p211), showing the 'circle of emergence' (p220), i.e. that area which is subject to social emergence

The relation suggested in our research between the entrepreneurial mechanism provided by the EROS processes and the ontological emergence of novel structures led us to propose the model combining the two, which is set out in Figure 2.

We suggest that this model has considerable analytical power with regards to understanding the production of order at multiple levels and the articulation of types of pro-active processes that are associated with the construction of order in practice. This approach, we argue, may benefit the study of entrepreneurship as a class rather than a set of sub-disciplines (Thornton, 1999), not only in a conceptual sense based on a rigorous treatment of emergence, but also by providing a methodological framework too. As stated earlier, there are few empirical studies which have explored facets of entrepreneurial embeddedness in the wider context of society - in part because of the methodological challenge.

If we are to study the dynamics of volatile new industries, we need to address the problem of making sense of multiple observations across different levels and showing linkages between levels as new structures (products, services, business models, value creating systems) emerge over time: an issue not just for the practicalities of our project, but also for entrepreneurship researchers generally. Such research is open to the development of congruent methodologies, i.e., in the words of the title of the paper, examining creativity requires creativity in methodological approach. Growing awareness of processual theories of entrepreneurship (Steyaert, 2007) have resulted in more sophisticated methodological approaches that relate the activities and behaviours of individuals over time to the firm and other contextual factors. Yet thus far, there has not been a methodological approach that has taken advantage of the possibilities offered by rigorous theoretical conceptualisations of emergence. We are thus experimenting creatively with data capture methods and analysis guided by this methodological conceptualisation. Pettigrew et al (2001, p. 698) have highlighted that the issues of multiple contexts and levels is a major analytical challenge for the study of organisational change: a key issue is, however, how many levels of context should be considered, and how many multiple processes do we include in our analyses? While we would not claim that our model (Figure 2) solves the problems of the social sciences that Pettigrew et al are addressing, the 4 processes that we have identified (Fuller et al 2006a,b) are grounded in empirical observations of entrepreneurial firms. This suggests that we have gone some way to capturing an entrepreneurial mechanism in the cases considered, that spans the individual, firm and industry network levels of analysis. It is therefore attractive to consider whether the model could be used as a framework to capture data concerning multiple observations at multiple levels of 
analysis over time, thus adding methodological value, as well as theoretical explanatory power (Fuller et al 2008).

Figure 2. Entrepreneurial mechanisms in the context of Sawyer's Emergence Paradigm

\begin{tabular}{|c|c|c|c|c|}
\hline & Experiments & Reflexive identity & $\begin{array}{l}\text { Organising } \\
\text { domains }\end{array}$ & $\begin{array}{lr}\text { Sensitivity } & \text { to } \\
\text { (changes } & \text { in) } \\
\text { conditions } & \end{array}$ \\
\hline $\begin{array}{l}\text { Social Structure } \\
\text { (Level E) }\end{array}$ & $\begin{array}{l}\text { The stability of } \\
\text { social structures } \\
\text { enables relative } \\
\text { experiments to } \\
\text { take place }\end{array}$ & $\begin{array}{l}\text { Stable structures } \\
\text { will provide } \\
\text { grounding to self- } \\
\text { identity. Also will } \\
\text { create tension as } \\
\text { between structures }\end{array}$ & $\begin{array}{l}\text { Much will be 'taken } \\
\text { for granted', such } \\
\text { that stable } \\
\text { emergents are } \\
\text { seen as innovative } \\
\text { and/or threatening }\end{array}$ & $\begin{array}{l}\text { By definition, } \\
\text { stable social } \\
\text { structures will } \\
\text { be resilient to } \\
\text { change }\end{array}$ \\
\hline $\begin{array}{l}\text { Stable Emergents } \\
\text { (Level D) }\end{array}$ & $\begin{array}{l}\text { The results of } \\
\text { 'successful' } \\
\text { experiments, are } \\
\text { ones supported } \\
\text { by social action }\end{array}$ & $\begin{array}{l}\text { Sense of self in } \\
\text { context, both } \\
\text { personal and at } \\
\text { the level of the firm }\end{array}$ & 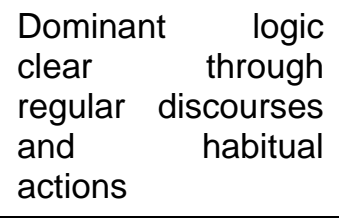 & $\begin{array}{ll}\text { Perhaps } & \\
\text { identified } & \text { as } \\
\text { challenges } & \text { or } \\
\text { threats } & \text { to } \\
\text { stability } & \\
\end{array}$ \\
\hline $\begin{array}{l}\text { Ephemeral } \\
\text { Emergents } \\
\text { (Level C) }\end{array}$ & $\begin{array}{l}\text { Whether as } \\
\text { thought } \\
\text { experiments, } \\
\text { discussions or as } \\
\text { short term } \\
\text { practice, the } \\
\text { transient nature of } \\
\text { these emergents } \\
\text { are a key part of } \\
\text { ascertaining the } \\
\text { legitimacy of } \\
\text { particular sets of } \\
\text { actions }\end{array}$ & $\begin{array}{l}\text { The shaping of the } \\
\text { individuals sense } \\
\text { of self and the } \\
\text { (new) ventures } \\
\text { sense of self within } \\
\text { the context of } \\
\text { existing markets } \\
\text { etc. }\end{array}$ & $\begin{array}{l}\text { The salient } \\
\text { organising domain } \\
\text { is that of } \\
\text { 'experiment', i.e. a } \\
\text { overt reflexivity that } \\
\text { links stability with } \\
\text { instability }\end{array}$ & $\begin{array}{l}\text { The } \\
\text { ephemeral } \\
\text { emergents are } \\
\text { the } \\
\text { manifestation } \\
\text { of sensitivity of } \\
\text { the individual } \\
\text { and } \\
\text { organisation }\end{array}$ \\
\hline $\begin{array}{l}\text { Interaction } \\
\text { (Level B) }\end{array}$ & $\begin{array}{l}\text { Interactions } \\
\text { experiments are } \\
\text { constrained by } \\
\text { existing } \\
\text { emergents and } \\
\text { structures. The } \\
\text { introduction of } \\
\text { new discourses } \\
\text { and meaning into } \\
\text { the firm from } \\
\text { external } \\
\text { structures (e.g. } \\
\text { new industries or } \\
\text { new technologies) } \\
\text { produces changes } \\
\text { in interactions and } \\
\text { emergents. }\end{array}$ & $\begin{array}{l}\text { Discourse patterns } \\
\text { for example, are } \\
\text { both part of a the } \\
\text { maintenance of } \\
\text { identity and the } \\
\text { renewing of } \\
\text { expressed identity. }\end{array}$ & \begin{tabular}{lr}
\multicolumn{2}{l}{ Discourse has } \\
been used ro \\
identify ephemeral \\
and r stable \\
emergents \\
entrepreneurial \\
practice
\end{tabular} & $\begin{array}{ll}\text { Interactions } & \\
\text { provide } & \text { a } \\
\text { mechanism } & \text { of } \\
\text { sensitivity } & \text { to } \\
\text { external } & \\
\text { conditions } & \end{array}$ \\
\hline $\begin{array}{l}\text { Individual } \\
\text { (Level A) }\end{array}$ & $\begin{array}{l}\text { Entrepreneurial } \\
\text { intention is seen } \\
\text { as an important } \\
\text { motivating reason } \\
\text { for entrepreneurial } \\
\text { action }\end{array}$ & $\begin{array}{lr}\text { Self-identity } & \text { can } \\
\text { form a stable } & \text { amergent and in } \\
\text { emen } & \text { this model provide } \\
\text { bottom } & \text { up } \\
\text { causality } & \text { of } \\
\text { emergence } & \end{array}$ & $\begin{array}{l}\text { Intention and } \\
\text { personality have } \\
\text { causal influence on } \\
\text { emergence in } \\
\text { entrepreneurial } \\
\text { settings }\end{array}$ & $\begin{array}{l}\text { The } \\
\text { individuals } \\
\text { cognitive } \\
\text { awareness } \\
\text { and openness } \\
\text { to change / } \\
\text { resilience will } \\
\text { be causal to } \\
\text { emergents }\end{array}$ \\
\hline
\end{tabular}




\section{Developing an empirical test bed in the creative industries sector}

Acts of individual creativity that result in artistic, social or cultural capital may not in themselves realise economic value, or be widely available, reproducible or disseminated as products or services outside the initial act of creation. In this case, the 'value creating system' that has emerged may be of enormous artistic significance, but the economic potential remains - perhaps intentionally so - untapped (indeed, some might claim this ostensible gratuitousness to be a qualifier of artistic acts). Thelwall (2007) refers to such 'first order' activities, where endeavour is intrinsically linked to the human labour involved, and is therefore inherently nonscalable. Here, the expertise of individuals is the core asset upon which success is based; it is unlikely that such resources as these can be replicated in line with the requirements of further growth within the sector. This is in contrast to 'second order' activities, such as buying the CD of a music performance where scalability has been achieved through removal of the expert skills through reproduction to meet consumer demand and spread appreciation.

In moving from first order to second order activities, the value creating system is inevitably extended to include more actors with different sets of values, vocabularies and discourses, as the dynamic between converting artistic, cultural and intellectual capitals to economic capital is explored. Of course, this transition from first order to second order activities is not necessarily innovative, or entrepreneurial, if 'traditional' business models are at the heart of the process: discussions tend to focus on contractual arrangements around established costs and revenues in accordance with likely consumer demand (Caves, 2000). Such systems are well understood, stable, with relatively predictable inputs and outputs. However, as we have stated earlier, new digital technologies have thrown up innovative new possibilities that can challenge, disrupt and may even overthrow existing revenue streams and industry patterns. It is this indeterminacy of outcome, the dynamic and unpredictable, the unknown shape or character of scalability in new industries, and how it will be achieved, that resonates with the tenets and underpinning assumptions of complexity theory. And it is here that we believe our framework has the methodological potential to capture and make sense of multiple observations across different levels of analysis and show linkages between levels as new phenomena (products, services, business models) emerge over time. We argue that in identifying and linking the unstable and ephemeral emergents that inevitable arise during creative collaborations - the twists and turns, unformed explorations, failed experiments, discarded and retained ideas -- to entrepreneurial, processes that preserve artistic and creative value, we can gain much improved insight into how creative individuals operate and achieve sustainability in conditions of high uncertainty.

\section{Observations from the research data}

The purpose of a methodology is to give theoretical and conceptual sense to observed data. Our gaze is towards empirical emergent ontological properties that have an influential effect on the shape and sustainability of the system we are observing. In practice, this means keeping an eye on the group of actors fore grounded in the study and on the artefacts, discourses and exchanges produced. Our analytical perspective is value creation, as this is the instrumental goal of the research; how is value created/captured? Thus, our analytical question is the relationship between the production of (ephemeral) emergent properties and their stability in relation to 'value'.

Exposure to the projects (Sensory Threads, Gesture and Embodied Interaction, and IT-Innovation) has afforded us a rich stream of data and connections that will take many months to analyse. In this limited space, it is only possible to identify some preliminary outcomes that are nonetheless highly promising. Using our conceptualisation and our framework, we were able to identify and track the emergence of 'stable emergents':

- Sensory Threads: the 'Rumbler' a novel interactive soundscape device

- Gesture: a unique combination of skill-sets in the sound/motion capture domain, supported by robust and re-usable (computer program) code

- IT-Innovation: a potential business model as yet untested

What was particularly interesting in observing the inter-activity between agents was the way that values associated with creativity or technicality interacted with economic value capture. These 'stable emergents' arose during the period of the projects from very early stage ideas that were not well articulated at the outset of CREATOR. As discussions in the rich interdisciplinary milieu progressed, possible trajectories were identified and tested out, either as thought experiments, shared metal models, or sometimes as rough working prototypes. At some point, these 'ephemeral emergents' were narrowed down to the most promising variant: at this point the transition from ephemeral to stable occurs. We would moot that this is the point at which discussions shift from value creation to value capture. We will develop this significant outcome further as contribution to the entrepreneurship and innovation literatures. 
We would also moot that what sustained the dynamics of the interactions was the anticipation of value. Rosen (1985) suggested that the ability of a system to anticipate its own future ('anticipatory systems') distinguishes living (evolutionary) systems from non-living, non-evolving, systems (We paraphrase Rosen). Given our keen interest in value creation, the question 'What value' is anticipated by the actors in the system and how this sustains the dynamics?', is a continuing part of the analysis. However, it is clear from our initial analysis that technical solutions, artistic experiences, reputations, fun, public credibility (i.e. a mix of human, social and cultural capitals) are as powerful in the sustainability of the dynamics as the anticipation of economic rents in the cases we are observing. We would posit that the dynamics of emergence in creative industries require anticipations of multiple forms of value, and that these can be linked to individual, organisational and sector-level ontologies, i.e. what meaningfully exists at a recognisable unit of analysis. The nature of values anticipated guides sensitivity to environment, organising domains, reflexive identity and the emergent evaluation and purpose of experimental practice.

The interrelationships between agents, consolidated by trust grounded in shared creative practice, which in turn motivates the anticipation of mutually recognised value, can be theorised as a 'value creating system'. In an active value creating system, value is created by transformation or conversion of capitals. Activity therefore involves some form of conversion process involving interaction between agents. If what is produced has sustainable value, then it will have changed or shaped structure (e.g. habits, patterns of behaviour, power relationships, anticipations, resource flows). The nature of structural change is unpredictable and is emergent from the interactions. It may be ephemeral (short-lived), but during its existence, exerts causal power, as part of structure, i.e. it influences (empowers, or constrains, or guides) the interactions between agents.

Such insights help us to understanding the nature of the economic structures in which creative activities within the digital economy will produce economic value. Put simply, a narrow focus on value capture (property rights, business model, market exchanges), does not explain how value is produced, for example as social, cultural and human capital, (Bourdieu 1986), nor how changes in social patterns and habits (consumption, desires, practices), whose stability creates the possibility of value capture, are caused through the presence of value creating systems.

\section{Conclusion}

This paper presents work-in-progress to test and demonstrate a methodological approach that takes advantage of possibilities offered by a theoretical conceptualisation of emergence. We present to what extent we have been able to resolve at least some of the methodological concerns raised at the outset of this discussion. Through testing our framework, we will be able to assess to what extent there is the potential to capture, in principle, the emergence of any novel form, be it product, service, new business model, firm, or behaviour in the creative industries sector.

In doing so, we hope to gain insight into how creative individuals and groups achieve sustainability that will be valuable to policymakers, practitioners and educators. Our immediate findings are that it is possible to conceive of emergence through interactions of multiple levels and to narrow down the salient aspects of a whole system of value creation and value capture, reducing the risk of failing to recognise causes outside the immediate gaze of those interested in value capture, which are of public and national interest.

\section{$\underline{\text { References }}$}

Aldrich, H.E. and Martinez, M.A. (2001), Many are Called, but Few are Chosen: An Evolutionary Perspective for the Study of Entrepreneurship, Entrepreneurship: Theory \& Practice 25, 4 (Summer), pp. 41-57.

Amabile, T. M. 1996. Creativity in context. (Update to The social psychology of creativity.) Boulder, CO: Westview Press.

Archer, M., (1995), Realist Social Theory: The Morphogenetic Approach, Cambridge: Cambridge University Press.

Bourdieu, P. (1986). The Forms of Capital. Handbook of theory of research for the sociology of education. J. E. E. Richardson. New York, Greenwood: 241-258.

Burnes, B. (2005), Complexity theories and Organisational Change, International Journal of Management Reviews 7, 2, pp. 73-90.

Busenitz, L.W., West, I., G. Page, Shepherd, D., Nelson, T., Chandler, G.N. and Zacharakis, A. (2003), Entrepreneurship Research in Emergence: Past Trends and Future Directions, Journal of Management, 29, 33, pp. 285-308.

Caves. R.E. (2000), Creative Industries, Contracts between arts and commerce, Harvard University Press: Cambridge, Massachusetts and London, England. 
.Chesbrough, H.W., W. Vanhaverbeke, and J. West, Open innovation : researching a new paradigm. 2006, Oxford: Oxford University Press. xvii, $373 \mathrm{p}$.

Christensen, C.M. (1997), The Innovator's Dilemma: When New Technologies Cause Great Firms to Fail, Boston, MA: Harvard Business School Press.

Davidsson, P. and Wiklund, J. (2001), Levels of Analysis in Entrepreneurship Research: Current Research Practice and Suggestions for the Future, Entrepreneurship: Theory \& Practice 25, 4 (Summer), pp 81 $-99$.

DCMS, (2007) Staying ahead: the economic performance of the UK's creative industries.

Down, S. (2006), Narratives of Enterprise: crafting entrepreneurial self-identity in a small firm, Cheltenham: Elgar.

Fischer, E., Reuber, A.R., Hababou, M., Johnson, W. and Lee, S. (1997), The Role of Socially Constructed Temporal Perspectives in the Emergence of Rapid Growth Firms, Entrepreneurship: Theory \& Practice, 22, 2 (Winter), pp. 13-30.

Fleming, L. and Sorenson, O. (2001),Technology as a complex adaptive system, Research Policy, 30, pp. 1019 - 1039.

Fletcher, D. (2006), Entrepreneurial processes and the social construction of opportunity, Entrepreneurship \& Regional Development, 18, 5, pp. 421-440.

Fuller, T. and Fewster, R. (2006), The Emergence of Tesco.com: A study of Corporate Entrepreneurship, paper presented at Babson-Kauffman Enterpreneurship Research Conference, Kelley Business School.

Fuller, T. and Moran, P. (2000), Moving beyond metaphor: towards a methodology for grounding complexity in small business and entrepreneurship research, Emergence; A Journal of Complexity Issues in Organizations and Management, 2, 1, pp. 50-71.

Fuller, T. and Moran, P (2001), Small enterprises as complex adaptive systems: a methodological question?, Entrepreneurship and Regional Development, 13, 1, pp. 47-63.

Fuller, T. and Warren, L (2006a), Entrepreneurship as foresight: A complex social network perspective on organisational foresight, Futures, Journal of Policy, Planning and Futures Studies, 38, 7, pp. 956 971.

Fuller, T. and Warren, L. (2006b), Complex Explanations of Order Creation, Emergence and Sustainability as Situated Entrepreneurship in Christensen, P.R. and Poulfelt, F. (eds), RENT XVIII Anthology 2005: Managing Complexity and Change in SMEs: Frontiers in European Research, Edward Elgar, Cheltenham, pp. $136-155$.

Fuller, T., L. Warren and P. Argyle (2007), Sustaining entrepreneurial business; a complexity perspective on processes that produce emergent practice, International Entrepreneurship and Management Journal, 4, 1, pp. 1-17.

Fuller, T., Moran P. and Argyle, P.. (2004), Entrepreneurial foresight; a case study in reflexivity, experiments, sensitivity and reorganisation, in Tsoukas, H. and Shepherd, J. (eds), Managing The Future: Foresight in the Knowledge Economy, Blackwell Publishing, Oxford, pp. 171-78.

Fuller, T., Warren, L., Argyle, P. and Welter, F, (2008), A complexity perspective on entrepreneurship: a new methodology for research in high velocity environments, paper accepted for British Academy of Management conference, November.

Garnsey, E. and Heffernan, P. (2005), High technology clustering through spinout and attraction: the Cambridge case, Regional Studies, 39, 8, pp. 1127-44.

Gartner, W.B. (1993), Words lead to Deeds: Towards an Organizational Emergence Vocabulary, Journal of Business Venturing, 8, pp. 231-239.

Garud, R. and Karnoe, P. (2003), Bricolage versus breakthrough: distributed and embedded agency in technology entrepreneurship, Research Policy, 32, pp. $277-301$.

Hearn, G. and C. Pace, Value-creating ecologies: understanding next generation business systems. Foresight, 2006. 8(1)

Houchin, K. and MacLean, D. (2005), Complexity theory and strategic change: an empirically informed critique, British Journal of Management, 16, 2, pp. 149-66.

Jack, S.L. and Anderson, A.R. (2002), The effects of embeddedness on the entrepreneurial process, Journal of Business Venturing, 17, 467-487.

Lepak, D. P., K. G. Smith, and MS Taylor, (2007). "Value creation and value capture: a multilevel perspective." Academy of Management Review 32(1): 180-194.

Lichtenstein, B.B., Carter, N.M., Dooley, K.J. and Gartner, W.B. (2007), Complexity dynamics of nascent entrepreneurship, Journal of Business Venturing, 22, 236-261.

Lichtenstein, B.B., Dooley, K.J. and Lumpkin, G.T. (2006), Measuring emergence in the dynamics of new venture creation, Journal of Business Venturing, 21, 2, pp. 153-75.

Lichtenstein, B.M.B. (2000a), Emergence as a process of self-organizing - New assumptions and insights from the study of non-linear dynamic systems, Journal of Organizational Change Management, 13, 6, pp. 526-44. 
Lichtenstein, B.M.B. (2000b), Generative Knowledge and Self-Organized Learning Reflecting on Don Schön's Research, Journal of Management Inquiry, 9, 1, pp. 47-55.

Lichtenstein, B.M.B. (2000c), Self-organized transitions: A pattern amid the chaos of transformative change, Academy of Management Executive, 14, 4, pp. 128-141.

Lissack, M. (1997), Of chaos and complexity: managerial insights from a new science, Management Decision, 35, 3, pp. 205-218.

Low, M.B. and MacMillan, I.C. (1988), Entrepreneurship: Past Research and Future Challenges, Journal of Management 14, 2, pp. 139-61.

McKelvey, B. (2004), Towards a complexity science of entrepreneurship, Journal of Business Venturing, 19, 3, pp. 313- 29.

Pettigrew, A. M., Woodman, R. W., Cameron, K. S. (2001), Studying Organisational Change and Development: Challenges for Future Research, Academy of Management Journal, 44, 4, pp. 697 713.

Phan, P. (2004), Introduction: Entrepreneurship theory: possibilities and future directions, Journal of Business Venturing, 19, pp. 617-620.

Powell, D. (2002), Creative and cultural industries - An economic impact study for South East England Research report by David Powell Associates Ltd., for South East England Cultural Consortium and the South East England Development Agency

Rosen, R. (1985). Anticipatory systems : philosophical, mathematical and methodological foundations. Oxford, Pergamon.

Sarasvathy, S.D. (2001), Causation and effectuation: Toward a theoretical shift from economic inevitability to entrepreneurial contingency, Academy of Management Review, 26, 2, pp. 243-263.

Sawyer, R.K. (2005), Social Emergence: Societies as Complex Systems, Cambridge: Cambridge University Press.

Schumpeter, J.A. (1934), The Theory of Economic Development: An inquiry into Profits, Capital, Credit, Interest and the Business Cycle Cambridge, Mass: Harvard University Press.

Simon, H. A. (1957), Models of man: Social and rational. New York: Wiley

Simsek, Z., Lubatkin, M.H. and Floyd, S.W. (2003), Inter-Firm Networks and Entrepreneurial Behavior: A Structural Embeddedness Perspective, Journal of Management, 29, 3, pp. 427-442.

Smallbone, D. and Welter, F. (2006), Conceptualising Entrepreneurship in a Transition Context, International Journal of Entrepreneurship and Small Business, 3, 2, pp. 190-206.

Snowden, D. (2002), Complex acts of knowing: paradox and descriptive self awareness, Journal of Knowledge Management 6, 2, pp. 100-11.

Stacey, R.D. (2003), Strategic Management and Organisational Dynamics, the Challenge of Complexity, London: FT Prentice Hall.

Stacey, R.D., Griffin, D. and Shaw, P. (2002), Complexity and management, Fad or radical challenge to systems thinking?, London: Routledge.

Steyaert, C. (2007), 'Entrepreneuring' as a conceptual attractor? A review of process theories in 20 years of entrepreneurship studies, Entrepreneurship \& Regional Development, 19, 6, pp. $453-477$.

Thelwall, S. (2007), Capitalising Creativity Developing earned income streams in Cultural Industries organisations, Cultural Snapshot No 14 , http://proboscis.org.uk/publications/SNAPSHOTS capitalcreativity.pdf, accesses 30/08/2008

Thornton, P.H. (1999), The Sociology of Entrepreneurship, Annual Review of Sociology, 25, pp. 19-46. 